\title{
Impact of the pycnocline layer on bacterioplankton: diel and spatial variations in microbial parameters in the stratified water column of the Gulf of Trieste (Northern Adriatic Sea)
}

\author{
Gerhard J. Herndl ${ }^{1}$ \& Vlado Malačič ${ }^{2}$ \\ ${ }^{1}$ Institute for Zoology, University of Vienna, Althanstr. 14, A-1090 Vienna, Austria \\ ${ }^{2}$ Marine Biology Station Piran, Cesta JLA 65, YU-66330 Piran, Yugoslavia
}

\begin{abstract}
Diel variations in bacterial density, frequency of dividing cells (FDC) and dissolved organic carbon (DOC) in the stratified water column of the Gulf of Trieste were investigated at various depths. In the surface layers morning and afternoon DOC peaks (up to $10 \mathrm{mg} \mathrm{l}^{-1}$ ) were observed in 3 out of 4 diel cycles. Bacterial abundance remained fairly constant over the diel cycles; however, bacterial activity as measured by FDC showed pronounced peaks in late afternoon and dawn coinciding with the DOC maximum concentrations. The pycnocline layer exhibited DOC concentrations similar to those of the overlying waters. The frequency of dividing cells (FDC), however, remained high throughout the entire diel cycle. The observed pronounced diel variations in bacterial production were therefore largely restricted to the layers well above the pycnocline; bacterial production contributed less than $20 \%$ to the overall diel production (500 to $1000 \mu \mathrm{g} \mathrm{C} \mathrm{l}^{-1} \mathrm{~d}^{-1}$ ) in the uppermost $5 \mathrm{~m}$ water body. Highest diel production was found in the pycnocline layer at the end of the phytoplankton bloom (June and July) probably reflecting the formation of nutrient-enriched microzones around decaying phytoplankton cells due to reduced sinking velocities in the pycnocline layer. Additionally, FDC-based bacterial secondary production estimates were compared with in situ incubations of dialysis bags filled with $2 \mu \mathrm{m}$ filtered seawater for $24 \mathrm{~h}$. Bacterial biomass production estimates based on FDC for the 5 and $10 \mathrm{~m}$ layer were 3 and 14 times higher, respectively. The observed variations of microbial parameters within different layers point to the importance of small-scale investigations in both time and space.
\end{abstract}

\section{INTRODUCTION}

The tight coupling of pelagic primary production and bacterial utilization of phytoplankton extracellular release has been demonstrated by numerous authors (Itturiaga \& Hoppe 1977, Wiebe \& Smith 1977, Larsson \& Hagström 1982, Bell 1983, Chrost 1983, Itturiaga \& Zsolnay 1983). This coupling provokes measurable diel variations in biological and related parameters in the water column. Significant diel variations of bacterioplankton activity in response to varying photosynthetic rates have been reported from various marine environments (Sieburth et al. 1977, Meyer-Reil et al. 1979, Krambeck 1984, Riemann et al. 1984, Fuhrman et al. 1985, Turley \& Lochte 1986). These studies clearly show high bacterial activity during daytime independ- ent of the method used. Additional studies (Sieburth et al. 1977, Spencer 1979, Ammerman \& Azam 1981, Burney et al. 1981) reveal a good agreement between bacterial activity and the amounts of various dissolved substances. Despite our knowledge on diel variations in bacterial biomass, its activity and related parameters, no attempt has been made - with the notable exception of Carlucci et al. (1986) - to investigate diel variations of several microbiological parameters in various layers of the water body concurrently.

Evidence has been presented in the literature that pronounced spatial variations in biological parameters occur within the water column due to diel activities of pelagic organisms. Nocturnal vertical migration and activity of zooplankton influences the content and composition of biological and chemical constituents in 


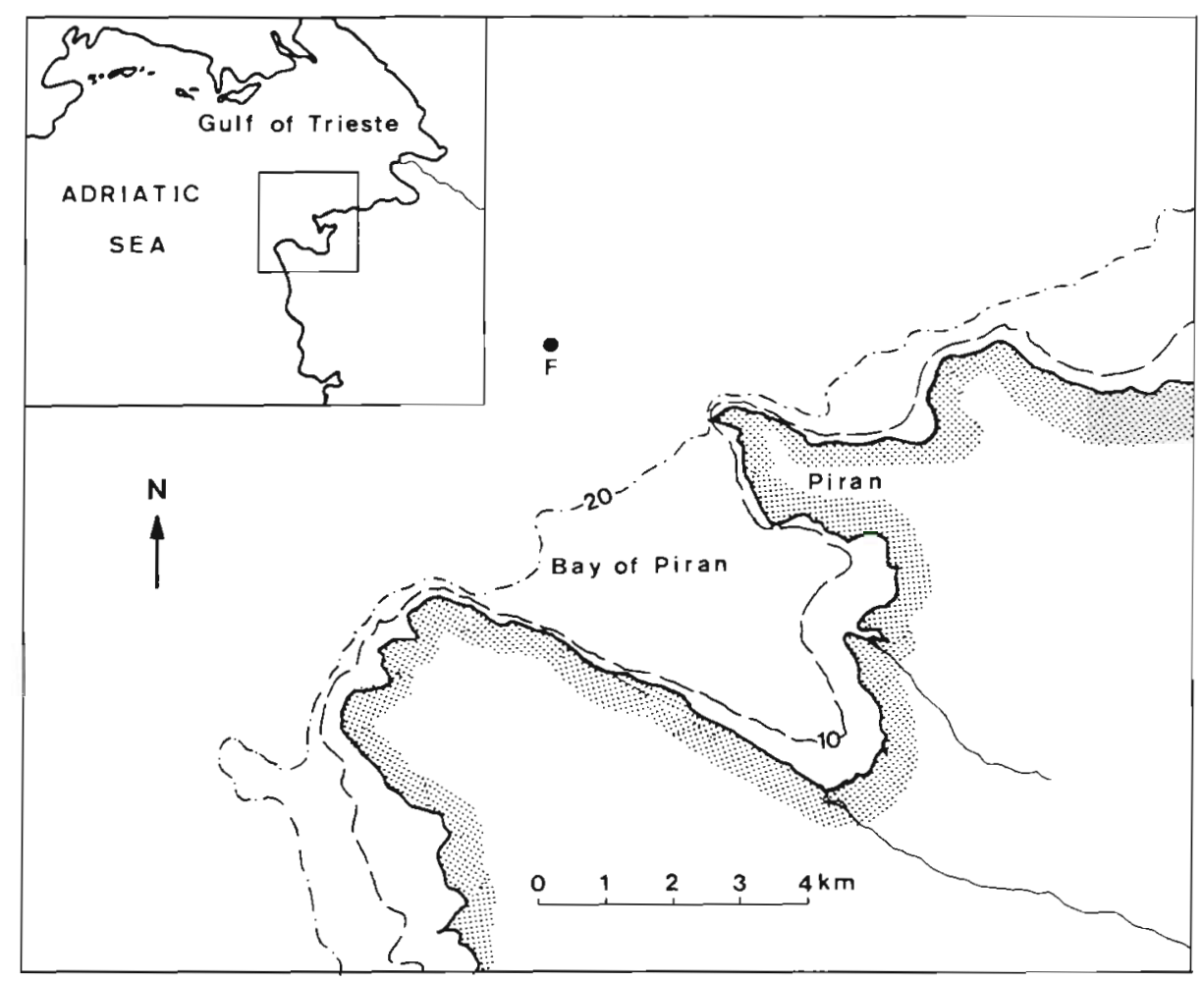

Fig. 1. Study area and position of sampling location $(F)$

near-surface layers (Lampert 1978, Copping \& Lorenzen 1980, Eppley et al. 1981, Riemann et al. 1986) and may enhance bacterial activity (Jørgensen et al, 1983). On the other hand, diurnal phytoplankton primary production in surface waters is believed to cause an enrichment in dissolved organic matter (DOM) in these layers (Carlucci et al. 1984, 1985, 1986); this improves conditions for bacterial growth. Sieracki \& Sieburth (1986), however, report on sunlight-induced growth delay of surface-layer bacteria incubated in bottles and submerged in outdoor aquaria. These authors conclude that direct or indirect photoinhibition of bacterial activities could be a significant factor in the diel cycling of organic matter in the euphotic zone (Sieracki \& Sieburth 1986)

All the above-mentioned processes contribute to diel and spatial heterogeneity of the water column. Further discontinuity in the water column is introduced by stratification, leading to a reduced material flux between the different layers (Hargrave \& Phillips 1986, Herndl et al. in press). As is true for other coastal embayments (Taft et al. 1980, Officer et al. 1984), the Gulf of Trieste (Northern Adriatic Sea) is characterized by strong stratification during summer. This may lead to hypoxia and occasionally to complete oxygen depletion of the near bottom layer (Stachowitsch 1984, Faganeli et al. 1985).

The purpose of this study is to determine the diel variations in bacterial density, bacterial activity and dissolved organic carbon in various depths of the stratified water column of the Gulf of Trieste. Sampling depths of each diel investigation period were adapted to the depth of the pycnocline; this enabled sampling in the close vicinity of this boundary layer since it was hypothesized that condensation of particulate organic matter (POM) in the pycnocline layer enhances bacterial activity. These studies of diel fluctuations will complement current investigations of seasonal aspects (Turk unpubl.). Specifically, it was asked whether diel fluctuations in microbial parameters necessitate a particular time of day for studying seasonal dynamics.

\section{MATERIAIS AND METHODS}

Investigations were carried out on 24 to $25 \mathrm{Apr}, 25$ to

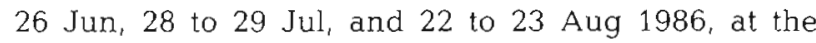
routinely sampled Stn F with a $22 \mathrm{~m}$ water column in the Gulf of Trieste (Northern Adriatic Sea) (Fig. 1).

A research vessel of the Marine Biology Station Piran was fixed at Position $\mathrm{F}$ by 3 anchors. For water sampling 51 Niskin bottles were used, and the sampling depths varied according to the depth of the pycnocline. In June, bacterial secondary production was estimated using $2 \mu \mathrm{m}$ filtered seawater from 5 and $10 \mathrm{~m}$ depth incubated in four $1 \mathrm{l}$ dialysis bags (Reichert Thomapor $0.2 \mathrm{~nm}$ pore diameter) at the respective depths for $24 \mathrm{~h}$ (Turley \& Lochte 1985, Herndl et al. in press). 
At the beginning of each diel measurement, temperature was recorded continuously throughout the water column to determine the depth range of the pycnocline. Standard methods were used for biological and physical properties. Salinity was determined by the high precision titration method described in Strickland \& Parsons (1972). Seawater for dissolved organic carbon (DOC) determination was gently vacuum-filtered through pre-rinsed $0.2 \mu \mathrm{m}$ Sartorius filters and stored in precombusted glass vials $\left(450^{\circ} \mathrm{C}\right.$ for $\left.12 \mathrm{~h}\right)$ in the dark at $4^{\circ} \mathrm{C}$ until analysis (generally within $14 \mathrm{~d}$ of sampling). DOC analyses were performed using a BeckmanTocamaster 915-B. Calibration standards were made up from a stock solution (1000 $\mathrm{mg} \mathrm{Cl}^{-1}$ ) of $2.125 \mathrm{~g}$ Reagent Grade anhydrous potassium biphthalate in $1 \mathrm{l}$ of double-distilled water. Samples were freed of inorganic carbon by acidifying to about pH 2 with $50 \mu \mathrm{l}$ $\mathrm{HCl}$ (conc. $2 \%$ ) and sparging with a stream of synthetic $\mathrm{CO}_{2}$-free air. At least 2 replicates were made for each sample.

Water samples $(10 \mathrm{ml})$ for bacterial abundance determination from both the water column and the dialysis bags were fixed with buffered formalin to a final concentration of $2 \%$ and stored refrigerated. Bacterial density was determined within $14 \mathrm{~d}$ of sampling by acridine orange direct epifluorescence counts (AODC) (Hobbie et al. 1977). The same filters were used for determination of the frequency of dividing bacterial cells (FDC) (Hagström 1984). Bacterial cell dimensions were determined from visual estimates during AODC, in which 100 to 120 rods and 50 to $70 \mathrm{cocci}$ were measured and the mean volumes calculated.

The precision of the methods used was tested on replicate estimates during the April sampling and is presented in Table 1 (DOC analyses were done routinely in duplicate).

Table 1. Coefficient of variation (CV) for replicate estimations on April sampling

\begin{tabular}{|ll|}
\hline Parameter & Average CV \\
\hline Bacteria & $0.3 \%$ \\
FDC & $4.3 \%$ \\
DOC & $1.9 \%$ \\
Mean of all replicate determinations & \\
\hline
\end{tabular}

\section{RESULTS}

The physical characteristics of the water column indicate that we sampled a well-stratified water body in all 4 diel cycles (Fig. 2). Fig $3 \& 4$ show the physical and microbiological parameters measured in April

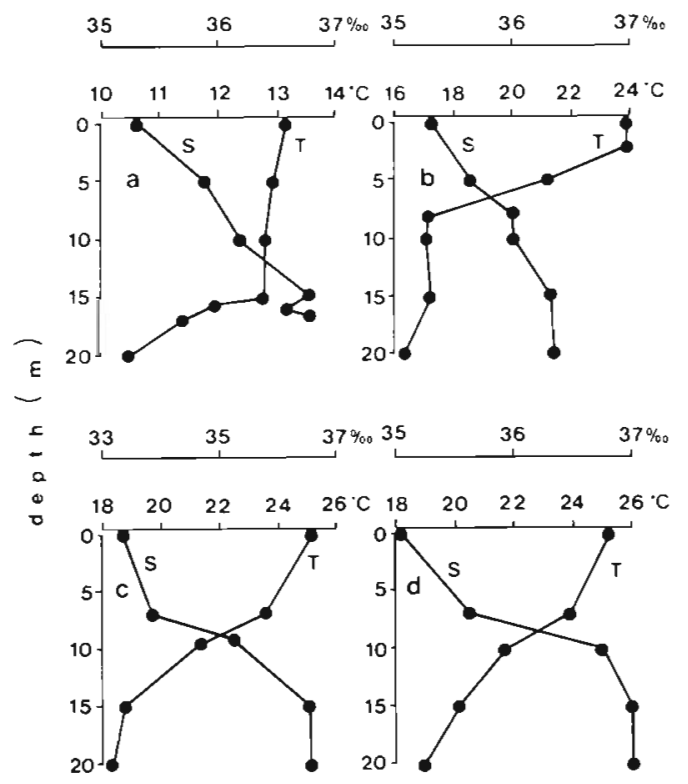

Fig. 2. Temperature and salinity profiles of the water column

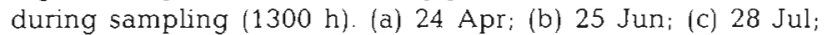
(d) 22 Aug 1986

(Fig. 3) and June (Fig. 4) of several depth layers over the diel cycle (July data not shown; in August only DOC was measured in addition to the physical parameters).

\section{Surface water layer}

One of the general trends in the surface layer $10.5 \mathrm{~m}$ sampling depth) regardless of sampling date was the low DOC content of approx. $1 \mathrm{mg} \mathrm{l^{-1 }}$ during daytime with an early morning peak in DOC of up to $5 \mathrm{mg} \mathrm{l}^{-1}$ around $0500 \mathrm{~h}$. This morning peak was observed in 3 out of 4 diel cycles (Fig. 4a); only the April DOC cycle deviated from this pattern with generally high DOC contents of the surface waters during night-time (Fig. 3a). Bacterial abundance remained fairly constant over the diel cycles; however, bacterial activity as estimated by FDC showed pronounced diel cycles with peaks in late afternoon and evening. This pattern was consistent in all 3 days of measurement.

\section{The 5 to $7 \mathrm{~m}$ water layer}

This layer was well above the pycnocline during all diel measurements (Fig. 2). As in the surface layer, DOC showed a marked early morning peak with values up to $10 \mathrm{mg} \mathrm{l}^{-1}$ (Fig. 4b). Bacterial activity declined in the evening with lowest FDC around midnight. In April, however, about $12 \%$ of the bacterial population was in a dividing stage at $0100 \mathrm{~h}$. Corresponding to the 

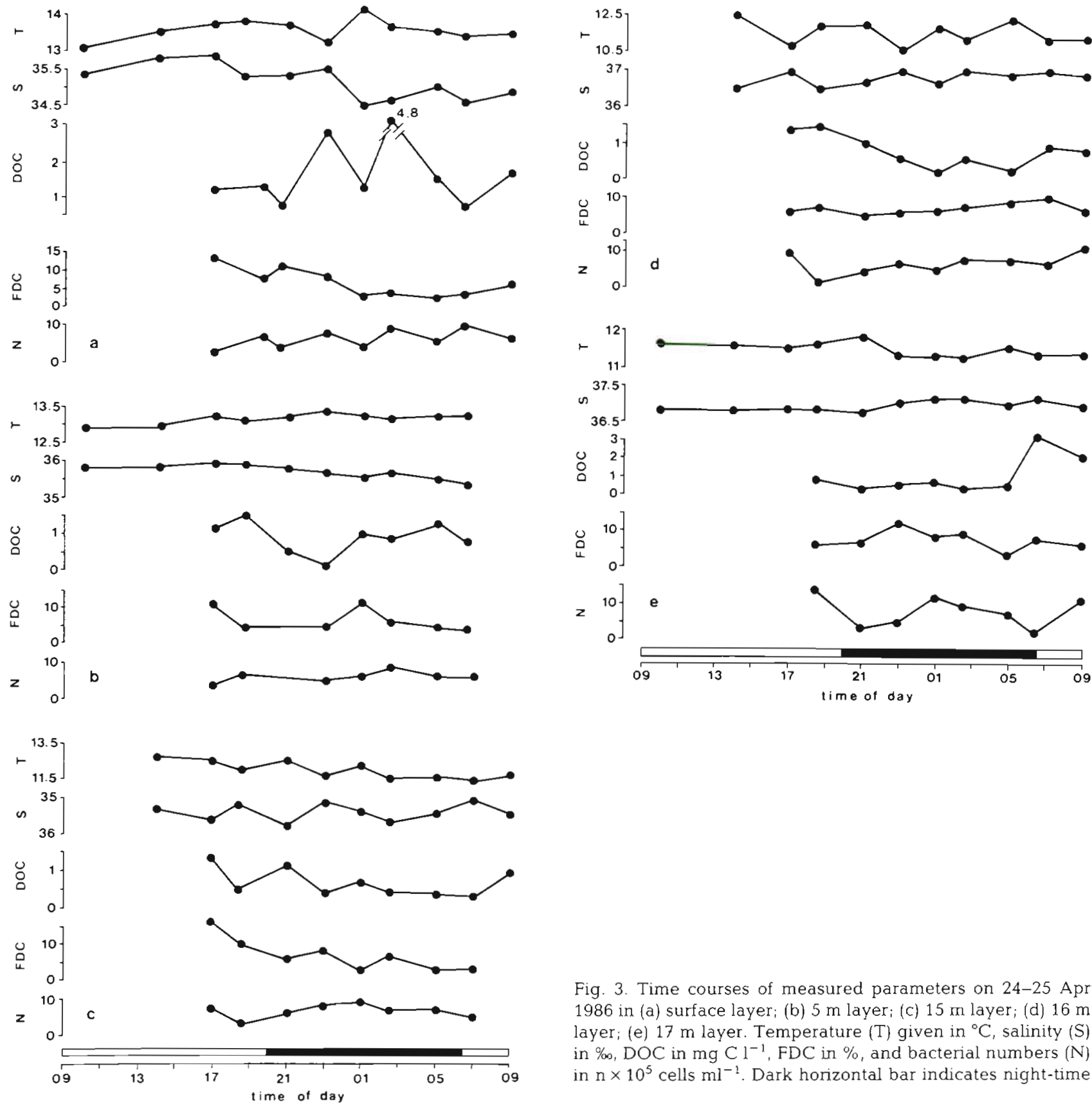

Fig. 3. Time courses of measured parameters on 24-25 Apr 1986 in (a) surface layer; (b) 5 m layer; (c) 15 m layer; (d) $16 \mathrm{~m}$ layer; (e) $17 \mathrm{~m}$ layer. Temperature (T) given in ${ }^{\circ} \mathrm{C}$, salinity (S) in $\%, \mathrm{DOC}$ in $\mathrm{mg} \mathrm{Cl} \mathrm{l}^{-1}, \mathrm{FDC}$ in $\%$, and bacterial numbers (N) in $\mathrm{n} \times 10^{5}$ cells $\mathrm{ml}^{-1}$. Dark horizontal bar indicates night-time

morning DOC peak, FDC values increased again at this time and varied only in a very narrow range over the entire diurnal cycle.

\section{Pycnocline layer}

DOC concentrations approached those of the overlying layers, with the same decreasing trends during night and peaks in the morning (Fig. $3 c \& 4 c$ ). FDC values remained high throughout the diel cycles, occa- sionally with even higher rates during the night (Fig. $3 d$, e \& 4c). Bacterial density in the pycnocline layer exhibited larger fluctuations than in the overlying water body.

\section{Dialysis bag incubations}

In June, concurrently with the diel parameter measurements, bacterial secondary production was estimated by means of $2 \mu \mathrm{m}$ filtered seawater filled in dialysis bags and incubated for $24 \mathrm{~h}$. In $5 \mathrm{~m}$ depth, 
bacterial density within the dialysis bags increased from $3.37 \times 10^{5}$ to $10.15 \times 10^{5}$ cells $\mathrm{ml}^{-1}(\mathrm{SD}=3.78$, $\mathrm{n}=4$ ) or, expressed in turnover times of the bacterial population, a mean of $13.3 \mathrm{~h}(\mathrm{SD}=3.77, \mathrm{n}=4)$ is required for doubling bacterial density. While rods contributed $83 \%$ to the initial bacterial abundance, this percentage declined to $67.5 \%(\mathrm{SD}=6.4, \mathrm{n}=4)$ after the $24 \mathrm{~h}$ incubation period.

In the $10 \mathrm{~m}$ incubations bacterial abundance increased from $2.33 \times 10^{5}$ to $3.24 \times 10^{5}$ cells $\mathrm{ml}^{-1}[\mathrm{SD}=$ $0.09, n=4)$ which corresponds to a mean generation time of $42.5 \mathrm{~h}(\mathrm{SD}=3.8, \mathrm{n}=4)$. About $60 \%$ of the initial bacterial population consisted of rod-shaped bacteria. This proportion remained more or less unchanged during the incubation: after $24 \mathrm{~h}, 59 \%$ ( $\mathrm{SD}=9.8, \mathrm{n}=4$ ) of the bacteria were identified as rods

\section{DISCUSSION}

In the present study we sampled over 4 diel cycles from an anchored ship. It is unlikely that we sampled a strictly homogenous parcel of water over a diel cycle, although the temperature and salinity differences within the different layers over time are small. The possibility that an oscillating water body was sampled can be excluded since the main current direction roughly parallels the coast line, coming from the south and turning towards west in the Gulf of Trieste. We are aware of the fact that internal wave phenomena, in combination with patchiness, adds noise to our data. Although we sampled on a rather small scale in both space and time we probably lost some maximum and minimum concentrations of the parameters measured.

Nevertheless, it was possible to detect distinct diel variations in microbial parameters. DOC concentrations reached maximum values in the afternoon and at dawn regardless of depth. Only the surface layer in April deviated from this scheme and exhibited a more inconsistent pattern. The origin of the afternoon DOC maximum may be attributed to increased phytoplankton extracellular release during photosynthesis. Such an accumulation would imply that a greater amount of labile compounds of DOC are released by phytoplankton organisms diurnally than can be taken up by the microbial population. Higher concentrations and accumulations of various compounds of DOM during daytime have been recorded from other coastal areas, such as the Baltic Sea (Meyer-Reil et al. 1979, Hagström \& Larsson 1984) as well as from the open ocean (Burney et al. 1982, Johnson et al. 1983, Burney 1986).

In most of the measurements the early morning peak exceeded the afternoon DOC maximum; especially in June, dawn DOC concentrations reached $10 \mathrm{mg} \mathrm{l}^{-1}$. One explanation for this high DOC content in the
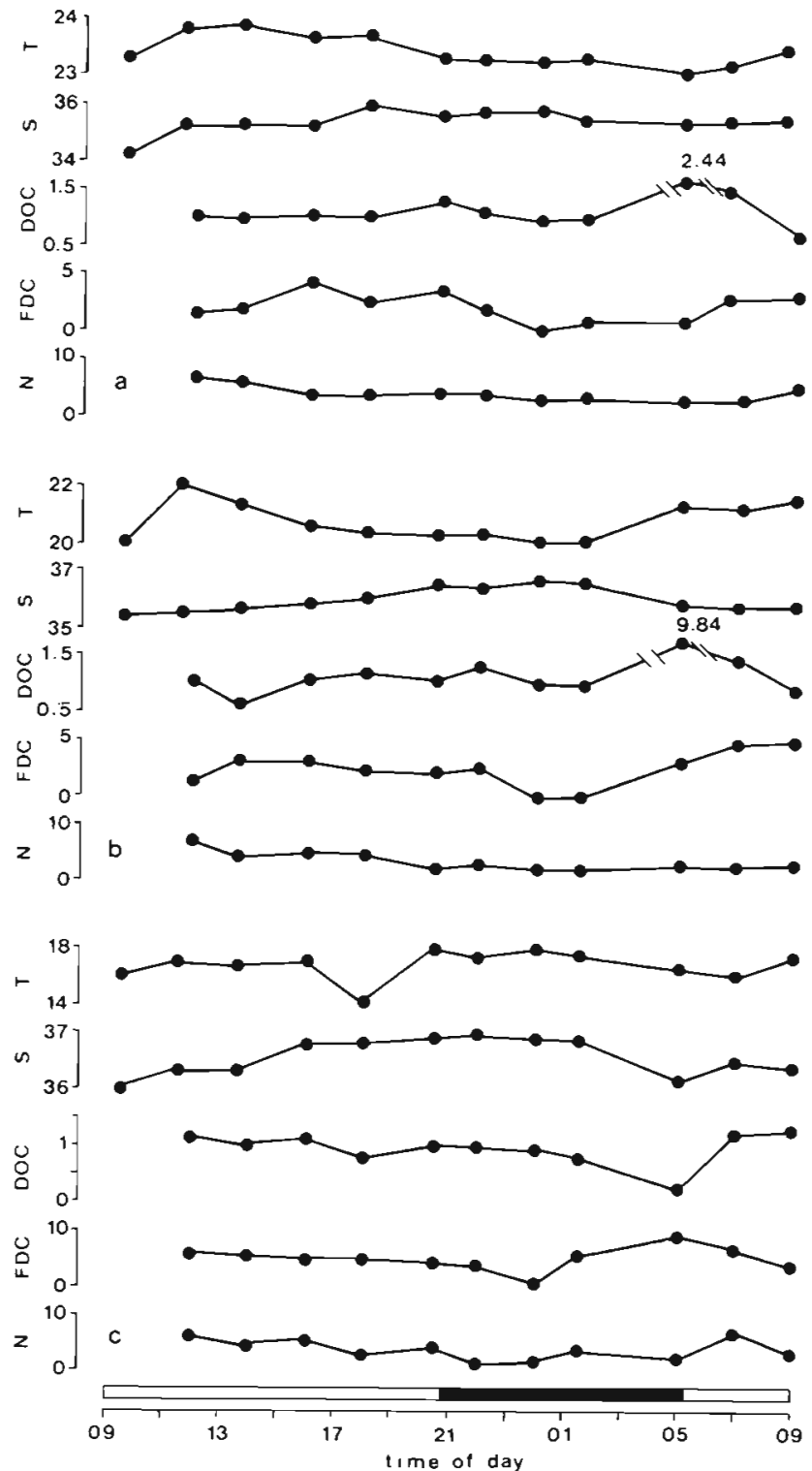

Fig. 4. Time courses of measured parameters on 25-26 Jun in (a) surface layer; (b) $5 \mathrm{~m}$ layer; (c) $15 \mathrm{~m}$ layer. For abbreviations see Fig. 3. Variables of the 2, 8 and $20 \mathrm{~m}$ layers are not shown

morning could be the loss of phytoplankton cellular material during grazing by herbivores. Lampert \& Taylor (1985) clearly demonstrated the influence of zooplankton diel migration on the distribution of nutrients in an eutrophic lake and Riemann et al. (1986) demonstrated that zooplankton grazing may increase the dissolved free amino acid pool potentially available for bacterial utilization. Early morning maxima of diel zooplankton feeding and excretion patterns were reported by Lorenzen (1967), Duval \& Geen (1976), and Mackas \& Bohrer (1976). In the layers above the pycnocline the observed diel pattern of DOC dynamics corresponded 



Fig. 5. Spatial and diel variation of FDC and sigma-t values in the stratified water column in (a) June and (b) July. Open symbols: daytime means; filled symbols: night-time; circles: FDC values in \%; triangles: sigma-t. Each point represents the mean of 6 measurements during day and night

Fig. 6. Spatial variation in bacterial production in the water column during daytime (white area) and night (dotted area) calculated from FDC; daylength in April: $12 \mathrm{~h}$, in June and July: $14.5 \mathrm{~h}$

roughly to bacterial activity as measured by the FDC method, with higher FDC rates during daytime. Fig. 5 presents 2 examples (June \& July) of pooled FDC day and night rates together with sigma-t values. A significant difference between day and night in FDC was obtained in all 3 diel cycles for the upper layers (down to $7 \mathrm{~m}$ ) (Mann-Whitney, $\mathrm{p}<0.1$ in all cases). Converting these FDC values to bacterial turnover rates using the equations for different temperature regimes (Hagström \& Larsson 1984), a mean generation time of $5.9 \mathrm{~h}$ was obtained in the surface layer during daytime (April), with a nocturnal value of $10.7 \mathrm{~h}$. This difference was smallest in July, with a turnover rate for day and night of 5.3 and $6.7 \mathrm{~h}$, respectively; in June the nocturnal generation time of 27.7 h was more than 4 times the diurnal ( $g=6.1 \mathrm{~h}$ ).

As indicated in Fig. 5 these pronounced diel differences in bacterial activity were largely restricted to the upper layers of the water column (see also Fig. 3 \& 4), while in the vicinity of the pycnocline no such diel cycles in bacterial activity were detectable. In April the mean diurnal generation time in the pycnocline layer was $9.0 \mathrm{~h}$ (nocturnal: $12.3 \mathrm{~h}$ ). These rates were therefore about one third higher than the corresponding surface layer values, although both during the day and night the FDC rates were higher at the pycnocline. Due to the different temperatures of the surface layer $\left(13.5^{\circ} \mathrm{C}\right)$ and pycnocline $\left(11.8^{\circ} \mathrm{C}\right)$, different equations (for 15 and $10^{\circ} \mathrm{C}$, respectively) were used for calculating the turnover rates. Thus, the generation time obtained in the surface layer may be arbitrarily underestimated and that in the pycnocline overestimated. In all the other diel cycles generation times of the pycnocline bacterial population ranged from 3.1 to $5.4 \mathrm{~h}$ with almost no differences between day and night.

Bacterial volume estimates reveal no significant diel fluctuations. All volume estimations for single days were therefore pooled. The mean biovolume of rods was $0.45 \mu \mathrm{m}^{3}$ ( $\left.\mathrm{SD}=0.18, \mathrm{n}=425\right)$, and of coccoid forms $0.06 \mu \mathrm{m}^{3}(\mathrm{SD}=0.019, \mathrm{n}=205)$. These values enable the estimation of bacterial production based on the FDC method and assuming the carbon-to-biovolume ratio given in Bratbak (1985). For this purpose mean FDC values were calculated separately for day and night periods and used for further calculation. Fig. 6 presents the estimated diel bacterial production and distinguishes between day and night production in different layers. Diel and spatial variation of bacterial production as well as monthly differences are obvious. Average production generally increased from April to July probably caused by a combination of increasing temperature and the senescent stage of the phyto- 
plankton bloom in June and July. While nocturnal bacterial production in April proceeded at a relatively high level (45 to $60 \%$ of diel production) throughout the uppermost $5 \mathrm{~m}$ layer, it declined dramatically in June and July. Nocturnal production contributed less than $20 \%$ to the diel production in the top $5 \mathrm{~m}$ water body.

In contrast to April, overall diel production in June and July in the pycnocline layer exceeded that of the surface waters (Fig. 6). During these 2 mo, nocturnal bacterial production contributed about 20 to $30 \%$ of the diel production. Although there were almost no differences in generation times between day- and night-time in the pycnocline layer, bacterial production was significantly lower during night due to reduced bacterial biomass probably caused by increased grazing pressure. This pattern of production (Fig. 6) indicates a tight coupling between phytoplankton primary production and bacterial activity; this was also observed by Linley et al. (1983), Lancelot \& Billen (1984) and Fuhrman et al. (1985). However, the enhanced microbial activity in the pycnocline layer (June and July) indicates that this coupling is not restricted to dissolved production of phytoplankton (which should occur predominantly in the upper layers where favorable light conditions provoke higher photosynthesis) but that particulate production enhances microbial activity as well: the sinking velocity of senescent phytoplankton cells may be reduced in this zone leading to an accumulation of moribund cells. As a consequence of prolonged residence time in combination with disruption or lysis of phytoplankton in the more dense water body DOC is released from the cells. This enhances bacterial activity. Lancelot \& Billen (1984) arrive at a similar conclusion in a study of phytoand bacterioplankton coupling in the North Sea. Mitchell et al. (1985) calculated that nutrient-enriched microzones around phytoplankton cells are large enough only in the thermocline layer to enhance bacterial growth. The role of the pycnocline in retarding the settling velocity of senescent phytoplankton and thus providing nutrients for bacterioplankton is further supported by the generally lower bacterial production in the $20 \mathrm{~m}$ layer ( 2 to $3 \mathrm{~m}$ above bottom) although the DOC measurements as well as the bacterial biomass distribution pattern give an inconsistent pattern only occasionally reflecting the higher bacterial production in the pycnocline layer. Clearly more information is required on the organic constituents of the DOM pool before a conclusive picture can be drawn; the determination of additional parameters (micro- and macrozooplankton density and activity) of these distinct layers is also necessary.

If we assume that bacterial production estimations based on the FDC method (Fig. 6) accurately reflect true conditions (see discussion below), grazing pressure on bacteria seems to be high. Recent studies on flagellate grazing indicate that these Protozoa are capable of controlling bacterial biomass (Fenchel 1982, Azam et al. 1983, Fuhrman \& McManus 1984). The nocturnal decline in bacterial biomass observed in this study is probably a combined effect of reduced production and flagellate grazing.

Currently, considerable efforts are being made on the precise determination of bacterial production. The use of various methods measuring different cellular activities (Riemann et al. 1984) makes a comparison of results difficult. New promising techniques have recently been developed (Kirchman et al. 1986). The incubation method using dialysis bags, however, has not received adequate attention. Its advantages over simple bottle incubations include avoidance of nutrient depletion during the course of incubation (dialysis bags with a molecular weight cut off of 12000 daltons were used), no significant wall-growth of bacteria, and successful deployment over at least one full diel cycle (Turley \& Lochte 1985, Herndl et al. in press). One serious shortcoming is the necessity of filtration procedures to exclude bacterivores and the poorly understood effect of confinement on bacterial activity (Ferguson et al. 1984). In this study we used $2 \mu \mathrm{m}$ Nuclepore filters through which almost the entire bacterial population passed. During epifluorescence microscopy only few flagellates were occasionally detected in samples drawn from dialysis bags after in situ incubation for $24 \mathrm{~h}$.

Fig. 7 a compares growth yields obtained by the FDC method over a diel cycle and by incubation of dialysis bags. In the $5 \mathrm{~m}$ layer the growth yields derived from FDC are similar to the mean growth rate obtained by incubations, at least during daytime. In the $10 \mathrm{~m}$ layer, however, the former exceed the latter over almost the entire cycle. Only around midnight are FDC-based growth rates lower than the mean rate obtained from the incubation technique. No data are available for the following morning; the FDC production estimate for the $10 \mathrm{~m}$ layer given in Fig. $7 \mathrm{~b}$ is thus most likely slightly underestimated if we assume an activity trend similar to that observed in the $5 \mathrm{~m}$ layer.

Bacterial biomass production estimates based on FDC for the 5 and $10 \mathrm{~m}$ layer are 3 and 14 times higher, respectively, than estimates based on dialysis bag incubations. Newell \& Fallon (1982) and Fuhrman et al. (1985) found production rates in seawater measured with FDC to be 2 to 7 times higher than the rates obtained with the ${ }^{3} \mathrm{H}$-thymidine method; dialysis bag incubations thus seem to give similar production rates to thymidine incorporation. Riemann \& Søndergaard (1984) reported values up to 21 times higher with the FDC than with the thymidine method in lakes. Possible 

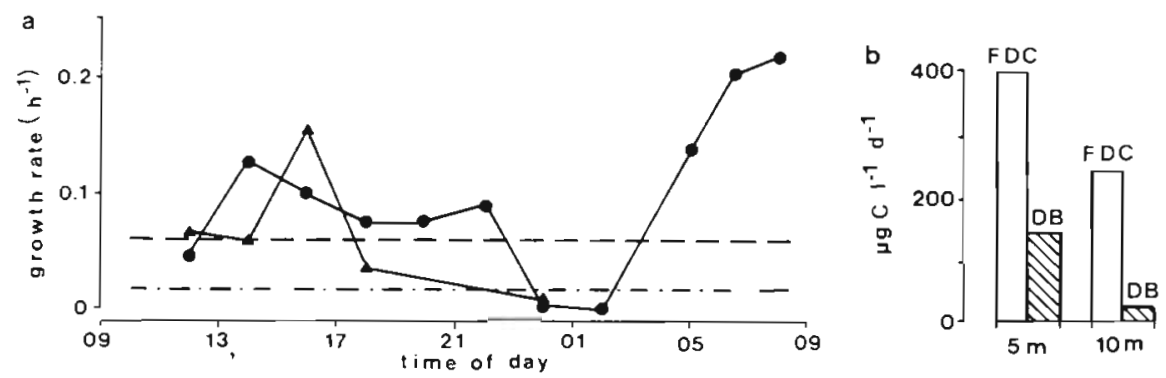

Fig. 7. Comparison between FDC and dialysis-bag-incubation based microbial parameters. (a) Variations in growth rates over the diel cycle obtained by FDC and average growth rate calculated from dialysis bag incubations. (•) FDC growth rates in the $5 \mathrm{~m}$ layer; (-- ) average growth rate from dialysis-bag-incubations. ( $\mathbf{1})$ FDC growth rates in the $10 \mathrm{~m}$ layer; (- -) corresponding mean of the dialysis bag-derived growth rate. (b) Difference in bacterial production estimates based on the FDC method and the dialysis bag (DB) technique for the $5 \mathrm{~m}$ and $10 \mathrm{~m}$ layers

reasons for these discrepancies are discussed in detail in Riemann et al. (1984). The preliminary results obtained in this study using dialysis bag incubations and the FDC method for bacterial production estimations are encouraging enough to justify a more thorough intercalibration of currently applied methods.

In summary, this study demonstrates the tight diel coupling between phytoplankton and bacterial activity. The observed variations of microbial parameters within different layers of the shallow water body examined point to the importance of small-scale investigations in both time and space. Although the water body was not uniform over time, the results obtained vary only in a narrow range, with similar trends even among different months. Similar diel investigations including more microbial variables and smaller depthintervals are planned to elucidate the diel rhythm of bacterioplankton in different layers of stratified water columns.

Acknowledgements. We gratefully acknowledge the assistance of F. Kravos, J. Forte and $V$ Bernetic during diel sampling under sometimes unfavorable conditions. We thank $M$. Stachowitsch for correcting the English text and G. Langthaler for drawing the figures. F. Azam, J. A. Fuhrman, J. G. Mitchell, and J. A. Ott read and improved the manuscript. DOC samples were analysed using a Beckman Tocamaster 915-B financed by FWF-Project No. 4717. This study was supported by FWF-Project No. 6138.

\section{LITERATURE CITED}

Ammerman, J. W., Azam, F. (1981). Dissolved cyclic adenosine monophosphate (CAMP) in the sea and uptake of cAMP by marine bacteria. Mar. Ecol. Prog. Ser 5: 85-89

Azam, F., Fenchel, T., Field, J. G., Gray, J. S., Meyer-Reil, L. A., Thingstad, F. (1983). The ecological role of watercolumn microbes in the sea. Mar. Ecol. Prog. Ser. 10: $257-263$

Bell, W. H. (1983). Bacterial utilization of algal extracellular products. 3 . The specificity of algal-bacterial interaction. Limnol. Oceanogr. 28: 1131-1143

Bratbak, G. (1985). Bacterial biovolume and biomass estimations. Appl. environ. Microbiol. 49: 1488-1493
Burney, C. M., Johnson, K. M., Sieburth, J. McN. (1981). Diel flux of dissolved carbohydrate in a salt marsh and a simulated estuarine ecosystem. Mar. Biol. 63: 175-187

Burney, C. M., Davis, P. G., Johnson, K. M. Sieburth, J. McN. (1982). Diel relationships of microbial trophic groups and in situ dissolved carbohydrate dynamics in the Caribbean Sea. Mar. Biol. 67: 311-322

Burney, C. M. (1986). Diel dissolved carbohydrate accumulation in coastal water of South Florida, Bermuda and Oahu. Estuar. coast. Shelf Sci. 23: 197-203

Carlucci, A. F., Craven, D. B., Henrichs, S. M. (1984). Diel production and microheterotrophic utilization of dissolved free amino acids in waters off Southern California. Appl. environ. Microbiol. 48: 165-170

Carlucci, A. F., Craven, D. B.. Henrichs, S. M. (1985). Surfacefilm microheterotrophs: amino acid metabolism and solar radiation effects on their activities. Mar. Biol. 85: 13-22

Carlucci, A. F., Craven, D. B., Robertson, K. J., Williams, P. M. (1986). Surface-film microbial populations: diel amino acid metabolism, carbon utilization, and growth rates. Mar. Biol. 92: 289-297

Chrost, R. J. (1983). Plankton photosynthesis, extracellular release and bacterial utilization of dissolved organic carbon (RDOC) in lakes of different trophy. Acta Pol. 32: 275-287

Copping, A. E., Lorenzen, C. J. (1980). Carbon budget of a marine phytoplankton-herbivore system with carbon-14 as a tracer. Limnol. Oceanogr. 25: 873-882

Duval, W. S., Geen, G. H. (1976). Diel feeding and respiration rhythms in zooplankton. Limnol. Oceanogr. 21: 823-829

Eppley, R. W., Horrigan, S. G., Fuhrman, J. A., Brooks, E. R., Price, C. C., Sellner, K. (1981). Origins of dissolved organic matter in Southern California coastal waters: experiments on the role of zooplankton. Mar. Ecol. Prog. Ser. 6: 149-159

Faganeli, J., Avcin, A., Fanuko, N., Malej, A., Turk, V., Tusnik, P., Vukovic, A. (1985). Bottom layer anoxia in the central part of the Gulf of Trieste in the late summer of 1983. Mar Pollut. Bull, 16: 75-77

Fenchel, T. (1982). Ecology of heterotrophic microflagellates. IV. Quantitative occurrence and importance as bacterial consumers. Mar Ecol. Prog. Ser. 9: 35-42

Ferguson, R. L., Buckley, E. N., Palumbo, A. V. (1984). Response of marine bacterioplankton to differential filtration and confinement. Appl environ. Microbiol. 47 49-55

Fuhrman, J. A., McManus, G. B. (1984). Do bacteria-sized marine eukaryotes consume significant bacterial production? Science 224: 1257-1260

Fuhrman, J. A., Eppley, R. W., Hagström, A., Azam, F. (1985) Diel variations in bacterioplankton, phytoplankton, and 
related parameters in the Southern California Bight. Mar. Ecol. Prog. Ser. 27: 9-20

Hagström, A. (1984). Aquatic bacteria: measurements and significance of growth. In: Klug, M. J., Reddy, C. A. (ed.) Current perspectives in microbial ecology. Am. Soc. Microbiol., Washington, D.C., p. 495-501

Hagström, A., Larsson, U. (1984). Diel and seasonal variation in growth rates of pelagic bacteria. In: Hobbie, J. E., Williams, P. J. leB. (ed.) Heterotrophic activity in the sea. Plenum Press, New York, p. 249-262

Hargrave, B. T., Phillips, G. A. (1986). Dynamics of the benthic food web in St. Georges Bay, southern Gulf of St. Lawrence. Mar. Ecol. Prog. Ser. 31: 277-294

Herndl, G. J., Faganeli, J., Fanuko, N., Peduzzi, P., Turk, V. (1987). Role of bacteria in the carbon and nitrogen flow between water-column and sediment in a shallow marine bay (Bay of Piran, Northern Adriatic Sea). P.S.Z.N.I. Mar. Ecol. (in press)

Hobbie, J. E., Daley, R. J., Jasper, S. (1977). Use of Nuclepore filters for counting bacteria. Appl. environ. Microbiol. 33: 1225-1228

Itturiaga, R., Hoppe, H.-G. (1977). Observations of heterotrophic activity on photoassimilated organic matter. Mar Biol. 40: 101-108

Itturiaga, R., Zsolnay, A. (1983). Heterotrophic uptake and transformation of phytoplankton extracellular products. Botanica mar 26: 375-381

Johnson, P. M., Davis, P. G., Sieburth, J. MCN. (1983). Diel variation in $\mathrm{TCO}_{2}$ in the upper layer of oceanic waters reflects microbial composition, variation, and possibly methane cycling. Mar. Biol. 77: 1-10

Jørgensen, N. O. G., Søndergaard, M., Hansen, H. J., Bosselmann, S., Riemann, B. (1983). Diel variation in concentration, assimilation and respiration of dissolved free amino acids in relation to planktonic primary and secondary production in two eutrophic lakes. Hydrobiologia 107: $107-122$

Kirchman, D. L., Newell, S. Y., Hodson, R. E. (1986). Incorporation versus biosynthesis of leucine: implications for measuring rates of protein synthesis and biomass production by bacteria in marine systems. Mar. Ecol. Prog. Ser. 32: $47-59$

Krambeck, C. (1984). Diurnal responses of microbial activity and biomass in aquatic ecosystems. In: Klug, M. J., Reddy, C. A. (ed.) Current perspectives in microbial ecology. Am. Soc. Microbiol., Washington, D.C., p. 502-508

Lampert, W. (1978). Release of dissolved organic carbon by grazing zooplankton. Limnol. Oceanogr. 23: 831-834

Lampert, W., Taylor, B. E. (1985). Zooplankton grazing in an eutrophic lake: implications of diel vertical migration. Ecology 66: 68-82

Lancelot, C., Billen, G. (1984). Activity of heterotrophic bacteria and the coupling to primary production during the spring phytoplankton bloom in the Southern Bight of the North Sea. Limnol. Oceanogr. 29: 721-730

Larsson, U., Hagström, A. (1982). Fractionated phytoplankton primary production, exudation release and bacterial production in a Baltic eutrophication gradient. Mar. Biol. 67 : $57-70$

Linley, E. A. S., Newell, R. C., Lucas, M. I. (1983). Quantitative relationships between phytoplankton, bacteria and heterotrophic microflagellates in shelf waters. Mar. Ecol. Prog. Ser. 12: 77-89
Lorenzen, C. J. (1967). Vertical distribution of chlorophyll and phaeopigments: Baha California. Deep Sea Res. 14: $735-746$

Mackas, D., Bohrer, R. (1976). Fluorescence analysis of zooplankton gut contents and an investigation of diel feeding pattern. J. exp. mar. Biol. Ecol. 25: 77-85

Meyer-Reil, L.-A., Bölter, M., Liebezeit, G., Schramm, W. (1979). Short-term variation in microbiological and chemical parameters. Mar. Ecol. Prog. Ser. 1: 1-6

Mitchell, J. G., Okuba, A., Fuhrman, J. A. (1985). Microzones surrounding phytoplankton form the basis for a stratified marine microbial ecosystem. Nature, Lond. 316: 58-59

Newell, S. Y., Fallon, R. D. (1982). Bacterial productivity in the water column and sediments of the Georgia (USA) coastal zone: estimates via direct counting and parallel measurement of thymidine incorporation. Microb. Ecol. 8: 33-46

Officer, C. B., Biggs, R. B., Taft, J. L., Cronin, L. E., Tyler, M. A., Boynton, W. R. (1984). Chesapeake Bay anoxia: origin, development, and significance. Science 223: 22-27

Riemann, B., Søndergaard, M. (1984). Measurements of diel rates of bacterial secondary production in aquatic environments. Appl. environ. Microbiol. 47: 632-638

Riemann, B., Nielsen, P., Jeppesen, M., Marcussen, B., Fuhrman, J. A. (1984). Diel changes in bacterial biomass and growth rates in coastal environments, determined by means of thymidine incorporation into DNA, frequency of dividing cells (FDC), and microautoradiography. Mar Ecol. Prog. Ser. 17: 227-235

Riemann, B., Jørgensen, N. O. G., Lampert, W., Fuhrman, J. A. (1986). Zooplankton-induced changes in dissolved free amino acids and production rates of freshwater bacteria. Microb. Ecol. 12: 247-258

Sieburth, J. MCN., Johnson, K. M., Burney, C. M., Lavoie, D. M. (1977). Estimation of in situ rates of heterotrophy using diurnal changes in organic matter and growth rates of picoplankton in diffusion culture. Helgoländer wiss. Meeresunters. 30: 565-574

Sieracki, M. E., Sieburth, J. McN. (1986). Sunlight-induced growth delay of planktonic marine bacteria in filtered seawater. Mar. Ecol. Prog. Ser. 33: 19-27

Spencer, J. J. (1979). Light-dark discrepancy of heterotrophic bacterial substrate uptake. FEMS Microbiol. Lett. 5: 343-347

Stachowitsch, M. (1984). Mass mortality in the Gulf of Trieste: the course of community destruction. P.S.Z.N.I. Mar. Ecol. 5: 243-264

Strickland, J. D. H., Parsons, T. R. (1972). A practical handbook of seawater analysis. Bull. Fish. Res. Bd Can. 167 : $1-311$

Taft, J. L., Taylor, W. R., Hartwig, E. O., Loftus, R. (1980). Seasonal oxygen depletion in Chesapeake Bay. Estuaries 3: 242-247

Turley, C. M., Lochte, K. (1985). A direct measurement of bacterial productivity in stratified waters close to a front in the Irish Sea. Mar. Ecol. Prog. Ser. 23: 209-219

Turley, C. M., Lochte, K. (1986). Diel changes in the specific growth rate and mean cell volume of natural bacterial communities in two different water masses in the Irish Sea. Microb. Ecol. 12: 271-282

Wiebe, W. J., Smith, D. F. (1977). Direct measurement of dissolved organic carbon release by phytoplankton and incorporation by microheterotrophs. Mar. Biol. 42: 213-233 